\title{
IMPROVEMENTS TO THE RETRIEVAL OF NO2 COLUMN FOR THE GOME-2 INSTRUMENT
}

\author{
Song Liu ${ }^{1, *}$, Pieter Valks ${ }^{1}$, Gaia Pinardi ${ }^{2}$, Isabelle De Smedt ${ }^{2}$, Huan $\mathrm{Yu}^{2}$, Steffen Beirle ${ }^{3}$ \\ ${ }^{1}$ Deutsches Zentrum für Luft- und Raumfahrt (DLR), Institut für Methodik der Fernerkundung (IMF), Oberpfaffenhofen, Germany \\ ${ }^{2}$ Belgian Institute for Space Aeronomy (BIRA-IASB), Brussels, Belgium \\ ${ }^{3}$ Max-Planck-Institut für Chemie (MPI-C), Mainz, Germany
}

Commission III, WG III/8

KEY WORDS: $\mathrm{NO}_{2}$ retrieval, GOME-2 satellite instrument, DOAS, stratosphere-troposphere-separation, AMF calculation

\begin{abstract}
:
$\mathrm{NO}_{2}$ is an important trace gas in both the stratosphere and troposphere. Since January 2007, the nadir-looking GOME-2 satellite instrument has been providing $\mathrm{NO}_{2}$ data on a global scale which is of great interest for climate research and atmospheric chemistry studies. In this contribution, we report on an improved algorithm for the retrieval of total and tropospheric $\mathrm{NO}_{2}$ columns from the
\end{abstract} GOME-2 instrument.

\section{INTRODUCTION}

In the stratosphere, nitrogen dioxide $\left(\mathrm{NO}_{2}\right)$ participates in the ozone cycle. In the troposphere, $\mathrm{NO}_{2}$ is a key air pollutant related to ozone formation, photochemical smog production, and eutrophication. Tropospheric $\mathrm{NO}_{2}$ is produced by both natural and anthropogenic processes, such as fossil fuel combustion, biomass burning, lightning and bacterial activities.

In the last decades, many in-situ, airborne, and satellite techniques have been applied to measure $\mathrm{NO}_{2}$ in the troposphere and stratosphere. The Global Ozone Monitoring Experiment-2 (GOME-2) satellite instrument has been providing a unique global $\mathrm{NO}_{2}$ dataset started from the year 2007. Currently there are two GOME-2 instruments operating in tandem on board EUMETSAT's Meteorological Operational satellites MetOp-A and MetOp-B, launched in October 2006 and September 2012 respectively. GOME-2 is an optical spectrometer sensing the solar irradiance and backscattered Earthshine radiance in the UV and visible spectral range. GOME-2 provides morning measurements at 9:30 local time with a spatial resolution of $80 \times 40 \mathrm{~km}^{2}$.

The operational GOME-2 near-real-time, off-line and reprocessed $\mathrm{NO}_{2}$ products are generated with the GOME Data Processor algorithm at the German Aerospace Center (DLR). This contribution focuses on the algorithm development for the retrieval of $\mathrm{NO}_{2}$ columns for the GOME-2 satellite instrument.

\section{NO2 RETRIEVAL}

The retrieval algorithm of total and tropospheric $\mathrm{NO}_{2}$ column for GOME-2 consists of several steps (Valks et al., 2011). (1) The differential optical absorption spectroscopy (DOAS) method (Platt and Stutz, 2008) is applied to determine the $\mathrm{NO}_{2}$ slant columns from GOME-2 in the visible wavelength region. $\mathrm{NO}_{2}$ slant columns are converted to initial total $\mathrm{NO}_{2}$ vertical columns by dividing a stratospheric air mass factor (AMF). The AMF is determined using a radiative transfer model based on the vertical $\mathrm{NO}_{2}$ profile and a set of forward model parameters, including the GOME-2 viewing geometry, surface albedo, clouds and aerosols. (2) Stratospheric $\mathrm{NO}_{2}$ columns are estimated and removed using $\mathrm{NO}_{2}$ measurements over clean regions based on the assumption of longitudinal homogeneity. (3) Tropospheric $\mathrm{NO}_{2}$ columns are derived by a tropospheric AMF based on tropospheric vertical $\mathrm{NO}_{2}$ profiles from chemistry transport model. The calculation of tropospheric AMF requires the same input parameters (i.e. viewing geometry, surface and cloud properties) as for the stratospheric AMF, but its dependency on these parameters is much stronger.

Three important parts of the total and tropospheric $\mathrm{NO}_{2}$ column retrieval for GOME-2 has been improved. (1) The retrieval of the $\mathrm{NO}_{2}$ slant column is performed with the DOAS method in an extended wavelength region (425-497 nm, Richter et al., 2011) with updated reference spectra. The GOME-2 slit function variations over time and along orbit are taken into account. The new version 6.1 of the GOME-2 level- $1 \mathrm{~b}$ data is applied. (2) The $\mathrm{NO}_{2}$ stratospheric column density is determined with the STRatospheric Estimation Algorithm from Mainz (STREAM, Beirle et al., 2016). (3) The tropospheric AMF is calculated using a new surface albedo climatology based on GOME-2 observations (Tilstra et al., 2017) and a priori vertical $\mathrm{NO}_{2}$ profiles are obtained from the chemical transport model TM5-MP (Williams et al., 2017).

\section{REFERENCES}

Beirle, S., Hörmann, C., Jöckel, P., Liu, S., Penning de Vries, M., Pozzer, A., Sihler, H., Valks, P., and Wagner, T., 2016. The STRatospheric Estimation Algorithm from Mainz (STREAM): estimating stratospheric $\mathrm{NO}_{2}$ from nadir-viewing satellites by weighted convolution, Atmos. Meas. Tech., 9, 2753-2779

Platt, U. and Stutz, J., 2008. Differential Optical Absorption Spectroscopy, Springer 
Richter, A., Begoin, M., Hilboll, A., and Burrows, J., 2011. An improved $\mathrm{NO}_{2}$ retrieval for the GOME-2 satellite instrument, Atmos. Meas. Tech., 4, 1147-1159

Tilstra, L., Wang, P., and Stammes, P., 2017. Surface reflectivity climatologies from UV to NIR determined from Earth observations by GOME-2 and SCIAMACHY, Journal of Geophysical Research: Atmospheres, 122, 4084-4111

Valks, P., Pinardi, G., Richter, A., Lambert, J.-C., Hao, N., Loyola, D., Van Roozendael, M., Emmadi, S., 2011. Operational total and tropospheric $\mathrm{NO}_{2}$ column retrieval for GOME-2, Atmos. Meas. Tech., 4, 1491-1514

Williams, J. E., Boersma, K. F., Le Sager, P., and Verstraeten, W. W., 2017. The high-resolution version of TM5-MP for optimized satellite retrievals: description and validation, Geoscientific Model Development, 10, 721 